\section{ODPRTOST DOSTOPA DO IZOBRAŽEVANJA IN E-UČENJE}

\section{POVZETEK}

Prost dostop do izobraževanja (open access to education) je temeljna paradigma informacijske družbe. Selektivni šolski sistem, tekmovalnost in točkovanje v nasprotju z razvojem in razmerami $v$ naši družbi izloča del generacije, zapre ji dostop do znanja. Znanje ni več privilegij elite, je splošna dobrina. Razvoj in vitalnost družbe sta odvisna od stopnje razvitosti prebivalstva. Intelektualna elita ne zadošča več, ker se je stopnjevala zahtevnost dela in življenja za vse ljudi. Razvoj človeškega kapitala zahteva odprt dostop do izobraževanja po formalni in neformalni poti. Informacijsko-komunikacijska tehnologija odpira pot do znanja vsem ljudem. Raziskave kažejo, da z uporabo interneta v Sloveniji premagujemo centralizacijo razvitega človeškega kapitala in izobraževalne ponudbe ter možnosti za učenje. Regije se izenačijo s centrom. Človek potrebuje vsaj štiriletno srednjo šolo, da se vključi. Funkcionalno nepismenih uporabnikov e-izobraževanja skoraj ni. Človek je pri e-izobraževanju odvisen od osebne motivacije za učenje. Za njim ni več učitelja. Sam mora odločati in voditi izobraževanje, ima pa zato brezmejne možnosti učenja. Na voljo mu je svetovna zakladnica, kar je pomemben dosežek globalizacije.

Ključne besede: Odprt dostop do znanja, centralizacija človeškega kapitala, človeški kapital, socialni kapital, uporaba interneta, e-izobraževanje, samostojno učenje, funkcionalna pismenost

$\mathrm{O}$ dprt dostop do izobraževanja (open access to education) je ena glavnih paradigem informacijske družbe. Znanje je postalo splošna dobrina in v novih razmerah življenja in dela ne more več biti samo privilegij elite. Razvite države si že desetletja prizadevajo, da bi odprt dostop do izobraževanja zagotovile prav vsem prebivalcem svoje države, ker sicer lahko nastopi velik problem: kdo bo preživljal ljudi, ki niso usposobljeni za sodobno delo in življenje. Opazni primeri takšnih prizadevanj so fakultete za Indijance na univerzah v Kanadi (na primer, University of British Columbia v Vancouvru), posebni programi za azilante in migrante na Danskem, da si pridobijo najmanj višješolsko izobrazbo, državne plače za odrasle, ki po predloženem programu nadaljujejo svoj študij na Švedskem, šole za domorodce v Avstraliji, podobna prizadevanja na Kitajskem in v Novi Zelandiji. Prizadevanja za odprt dostop do izobraževanja so močno prisotna $\mathrm{v}$ večini držav in lahko bi jih še veliko našteli.

Pogoj za to, da država zagotovi odprt dostop do izobraževanja vsem državljanom, je demokratizacija šolstva in izobraževanja odraslih. Oboje bi morali obravnavati enakovredno in podpirati z ukrepi tekoče državne politike. Porast človeškega kapitala, odločilni dejavnik ekonomskega uspeha in socialno-kulturnega razvoja, ne more več ostati odvisen le od
Prof. dr. Ana Krajnc

Filozofska fakulteta Univerze $v$ Ljubljani 
bolje izobraženih mladih generacij, ki bodo prihajale iz šol, ampak je treba izobrazbeno prekvasiti tudi odraslo populacijo, aktivni del prebivalstva in ljudi $\mathrm{v}$ tretjem življenjskem

Razvitost informacijske družbe je soodvisna od razvitosti celotnega prebivalstva. obdobju. Družbe so v času, ko se naglo stopnjuje zahtevnost dela in življenja, prisiljene, da se hitro odzivajo s povečanjem usposobljenosti in stopnje razvitosti vsega prebivalstva. $\mathrm{V}$ informacijski družbi smo odvisni od tega, kako je razvito celotno prebivalstvo.

Ne zadostuje več samo peščica visoko izobražene elite (Toffler, Alvin in Heidi, 1995).

OECD se pri napovedovanju razvojnih možnosti, vitalnosti, stabilnosti in vzpona gospodarstev posameznih držav zanaša na naslednje kazalnike:

- povprečno število let šolanja na državljana;

- stopnja funkcionalne pismenosti prebivalstva;

- povprečna pričakovana starost ljudi;

- umrljivost dojenčkov.

Odprte možnosti za delo so za ljudi dovolj razvite, da pri delu vnovčijo svoje sposobnosti in osebnostne lastnosti;

Razvitost informacijske družbe se povecuje z narašcanjm visokošolsko izobraženega prebivalstva.

\section{PROST DOSTOP DO IZOBRAŽEVANIA IN ČLOVEŠKI KAPITAL}

Dediščina industrijskega obdobja so množice funkcionalno nepismenih ljudi, ki so bili nekdaj zaposleni kot delavci v proizvodnji. Hitre spremembe so bistveno skrajšale čas za razvoj teh ljudi in njihovo usposabljanje in izobraževanje za bolj zahtevna dela. Države, ki so vzporedno vlagale $\mathrm{v}$ razvoj ljudi in robotizacijo ter novo računalniško podprto tehnologijo, imajo danes veliko manj nezaposljivih ali težko zaposljivih ljudi, od 20 do 30 odstotkov prebivalstva (Naisbitt John, 2000).

V preostalih, manj razvitih industrijskih družbah je stroj še naprej osrednja vrednota in človeka kot najpomembnejše gonilne sile informacijske družbe še niso odkrili. Ker se niso posebno posvečali izobraževanju in osebnostnem razvoju ljudi, se je tam masa funkcionalno nepismenih ali v današnjih pogojih dela in življenja trajno brezposelnih ljudi zelo povečala. V obsežni mednarodni študiji OECD o funkcionalni nepismenosti, v njej je med 22 državami sveta sodelovala tudi Slovenija, so ugotovili, da je v nekaterih državah število funkcionalno nepismenih doseglo tudi do 70 odstotkov prebivalstva. Slovenski del raziskave je pri nas vodil Andragoški center Slovenije (Možina Ester, 2003).

$\mathrm{V}$ takih primerih kritična masa za življenje in delo premalo usposobljenega prebivalstva postane tako velika, da lahko blokira manjšino prebivalstva, sposobnega za življenje in delo $\mathrm{v}$ informacijski družbi. Danci se sprašujejo, kdo bo preživljal funkcionalno nepismene, in zagovarjajo stališče, da mora biti vsak človek samozadosten. Kriteriji funkcionalne pismenosti se z razvojem dvigujejo. Danci ugotavljajo, da morajo imeti ljudje za funkcionalno pismenost najmanj višjo šolo. Pritiski mladih, da si pridobijo terciarno (višjo ali visoko) izobrazbo, so tudi v Sloveniji v zadnjih letih povzročili eksplozijo terciarnega izobraževanja. V razvitih državah (Angliji, Finski, Kanadi in podobno) 
se je to dogajalo pred tridesetimi leti. Za kmetijsko družbo je bil značilen razvoj osnovnega šolstva (primarno izobraževanje), za industrijsko družbo sistem srednjih šol, poklicna in strokovna izobrazba (sekundarno izobraževanje), za informacijsko pa višja in visokošolska izobrazba (terciarno izobraževanje).

V Angliji so poleg univerz razvili gosto mrežo visokošolskih institucij, tako imenovanih politehnik. Delovale so v vsakem večjem kraju za okoliško mladino. Pozneje so jih preimenovali $\mathrm{v}$ univerze in jih združili v enotno mrežo. Toda tudi to povečano število univerz in visokih šol ni moglo rešiti vseh potreb prebivalstva ob vstopanju v informacijsko družbo. Za odprt dostop do izobraževanja je bil potreben množičen študij. Rešitev so našli v alternativni obliki: študiju na daljavo. Open University vključuje do 250.000 študentov (ne glede na starost).

Študij na daljavo je postal prava »velesila za razvoj človeškega kapitala tudi na Nizozemskem, v Nemčiji (Fernstudium, Hagen), na Finskem, v ZDA, Kanadi, na Japonskem, v Avstraliji, na Kitajskem in $\mathrm{v}$ skandinavskih državah, kjer so v redko naseljenih predelih s pomočjo satelitov začeli prenašati izobraževalne programe in s tem odprli dostop do izobraževanja tudi v najbolj oddaljenih in zakotnih predelih svojih držav. Za odprt dostop do izobraževanja ne sme biti ovir.

Visoko razviti človeški kapital dopolnjuje še socialni kapital posameznika in inštitucij. Socialni kapital pospešujejo osebni stiki ljudi v urbanem okolju. Pričakujejo, da bo leta 2025 živelo v mestih 80 odstotkov prebivalcev, ki bodo delovali prek nove informacijsko-komunikacijske tehnologije (Toffler, Alvin in Haidi, 1995).

\section{SOCIALNI KAPITAL IN UČNA OKOLJA}

Množijo se oblike združevanja in medsebojnega povezovanja ljudi. Socialni kapital pokriva dve močni kategoriji: formalne institu- cije (podjetja, ustanove, zavodi, vladne službe, delo na projektih in podobno) in civilno družbo (interesno združevanje ljudi, društva, soseske, lokalna skupnost). Druga drugo dopolnjujeta. Oblike združevanja ljudi v okviru civilne družbe so fleksibilne, bliže interesom ljudi in njihovemu neposrednemu življenju. Rastejo iz konkretnih pogojev okolja. Najbolj neformalne oblike združevanja ljudi so prijateljske skupine, srečevanje bivših sodelavcev, bivših sošolcev, občasne povezave ljudi ob nekem dogodku, sorodstva, Študij na daljavo, ki omogoča cim večjemu številu prebivalstva pridobivati visokošlsko izobrazbo, še povecuje stopnjo razvitosti družbe. sostanovalci in internetno povezovanje $z$ drugimi na svetovnem spletu. Interesno združevanje ljudi v socialnem kapitalu dviguje kakovosti dela in življenja ljudi.

Ljudje si v združenjih civilne družbe pridobivajo družbeno moč zelo postopoma in le delno. $\mathrm{V}$ javnosti je društvom dodeljena glede na rezultate prizadevanj, na primer nekega društva, in po tistem, ko so to $\mathrm{v}$ javnosti že uveljavili. Velik delež opravljenega dela v civilni družbi predstavlja prostovoljno delo. Društva so bolj odprta kot uradne ustanove in dajejo ljudem več možnosti za nepo-

Interesno neformalno združevanje liudi $v$ socialnem kapitalu dviga kakovost dela in življenja ljudi. sredno delovanje in ustvarjalnost. Človek se laže izraža v društvih. Med sodelavci se stkejo globlje vezi. V njih je manj formalizmov in birokracije (Findeisen, Hebar, 2008).

Določena društva po določenem času delovanja lahko usahnejo, druga imajo zelo dolgo tradicijo. Če na njih preveč pritiskajo formalne, državne institucije, lahko v kratkem času tudi propadejo. Propadejo tudi, če ni kakovostnih odnosov med člani. Odločilna je kakovost in ne količina medsebojnih odnosov, sobivanja in sodelovanja. 
Institucije so bolj prilagojene skupnim interesom, splošnim ciljem in potrebam države, družbe, ciljem podjetja in so zato od posameznikov bolj oddaljene. Zagotavljajo, da delujejo razni sistemi (zaposlovanje, zbiranje davkov, proizvodnja, znanost, šolstvo in podobno). Zato so ljudje le delno motivirani za sodelovanje v njih, ker se podredijo splošnim ciljem. Združujejo večino družbene moči v neki državi in podpira jih zakonodaja in drugi pravni akti. Družbena moč pripada posameznikom po formalnem položaju in je javno priznana ne glede na rezultate dela in dosežke. Poti delovanja ljudi v formalnih institucijah so zelo določene in predpisane. Državni aparat in druge formalne institucije se teže prilagajajo novostim, se počasneje in teže spreminjajo in so bolj rigidne od društev in drugih oblik spontanega združevanja ljudi.

Vezi se tkejo med vladnim in nevladnim sektorjem, civilno družbo in znotraj posameznega sektorja. Vsak od njih dodaja pomembne kvalitete socialnemu kapitalu.

Zanima nas socialni kapital predvsem z vidika človeškega kapitala. V informacijski družbi smo zapisani vseživljenjskemu izobraževanju. Potrebno je, da se izobražujejo vse življenje vsi ljudje (ne glede na starost, spol, raso, poklic, formalno izobrazbo, socialni status in druge atribute) za vse svoje socialne vloge. Večina tega poteka neformalno. Odrasli se po organizirani institucionalni, formalni poti izobražujejo le še od 10 do 20 odstotkov, pravi Allen Tough. Vse preostalo izobraževanje poteka po razdrobljenih, osebnih poteh, ki so pisane na kožo učenca (Tough Allen, 1972).

Kakšna učna okolja se porajajo v institucijah, vladnih ustanovah, podjetjih in kakšna $\mathrm{v}$ društvih ter drugih oblikah spontanega združevanja ljudi?

Institucionalni sektor, vladni sektor se zanaša predvsem na formalno izobraževanje po predpisanih oblikah, ki je skupinsko organizirano in z zakonodajo podprto izobraževanje. Znanje, pridobljeno po tej poti, ima tudi uradno priznan
Društva so pomembna učna polja $\mathrm{v}$ sproščenih odnosih. Znanje se prenaša z opazovanjem, posnemanjem, osebnimi stiki, medsebojnimi razgovori, prepričevanjem, literaturo in s posameznimi primeri. Prevladuje izkustveno, doživljajsko in raziskovalno izobraževanje ter učenje $\mathrm{z}$ delom.

status in ugled. Učna okolja v društvih in drugih oblikah združevanja civilne družbe dajejo osnovo predvsem za neformalno izobraževanje in individualne oblike učenja. Dogaja se, da se ljudje učijo, ne da bi se tega posebej zavedali. Poti, kako se izobražujejo, so zelo osebne, raznolike in jih težko opišejo. Najbolj so opazni rezultati neformalnega izobraževanja.

\section{VIRTUALNA STVARNOST IN VIRTUALNA UČNA OKOLJA}

Poraja se še tretje, virtualno področje stikov z ljudmi. Nastajajo virtualni odnosi v tandemskem učenju, prijateljevanja na daljavo, strokovno povezovanje, mentorstvo in druge oblike virtualnih odnosov. V virtualni stvarnosti nastajajo tudi širše skupnosti ljudi, na primer strokovnjakov, ki se na svetu ukvarjajo s tridesetletno vojno, ljudi, ki so drugo svetovno vojno doživljali kot otroci, osebe $\mathrm{z}$ disleksijo in podobno. $\mathrm{V}$ virtualnem svetu nastajajo tudi nova, pomnožena učna okolja.

\section{KAKO SO SE Z NOVO INFORMA- CIJSKO-KOMUINIKACIJSKO TEH- NOLOGIJO POMNOŽILA UČNA OKOLJA?}

E-izobraževanje je na pohodu po vsem svetu. Predstavlja tisti, ugodni del globalizacije, ki vzbuja upanje za boljšo prihodnost $\mathrm{z}$ višjo stopnjo humanosti. 
E-izobraževanje pomnoži učenje ljudi na več načinov:

- pomnoži hitrost učenja;

- razširi učenje na celotno zakladnico znanja, ki ga človeštvo premore (globalizacija);

- dokončno omogoči odprt dostop do izobraževanja;

- spremeni izobraževanje v splošno dobrino namesto prejšnjega izobraževanja kot privilegija elite;

- znanje postane last vseh ljudi;

- izkustveno učenje dopolni virtualno učenje.

V družbeni praksi ostaja iz preteklega obdobja selektiven šolski sistem. Učence s slabšimi pogoji za učenje izloča. Ker imajo premalo točk, se ne morejo vpisati v srednjo šolo ali nadaljevati študij. Izobraževanje s tem ohranja nekdanjo funkcijo, da je privilegij elite. V nasprotju s tem je izobraževanje $v$ informacijski družbi splošna dobrina, dostopna vsem. Po podatkih iz devetdesetih let Zavoda Republike Slovenije za statistiko je bilo povprečno število let šolanja na prebivalca v Sloveniji 9,6. Izstopa samo ljubljanska regija, ki je daleč nad povprečjem (10,3 leta). Blizu povprečja so še obalno-kraška, gorenjska in mariborska, severnoprimorska, celjska, koroška regija. Notranjska in pomurska regija so globoko pod povprečjem $(9,2)$ v razvitosti človeškega kapitala. V razvitosti človeškega kapitala najbolj zaostajata posavska in dolenjska regija (9). Razviti del človeškega kapitala je skoncentriran v ljubljanski regiji, zato ima manjšo pomnoževalno moč na preostalo prebivalstvo.

Politična centralizacija preteklih obdobij se močno odraža po stopnji razvitosti prebivalstva, ker je večina izobraževalnih možnosti osredotočena v glavnem mestu. Če vzamemo število izobraževalnih organizacij v Ljubljani kot sto odstotkov, potem imajo tri najbolj razvite regije: mariborska, gorenjska in celjska, samo še 30, 21 in 20 odstotkov organizacije. Vse preostale

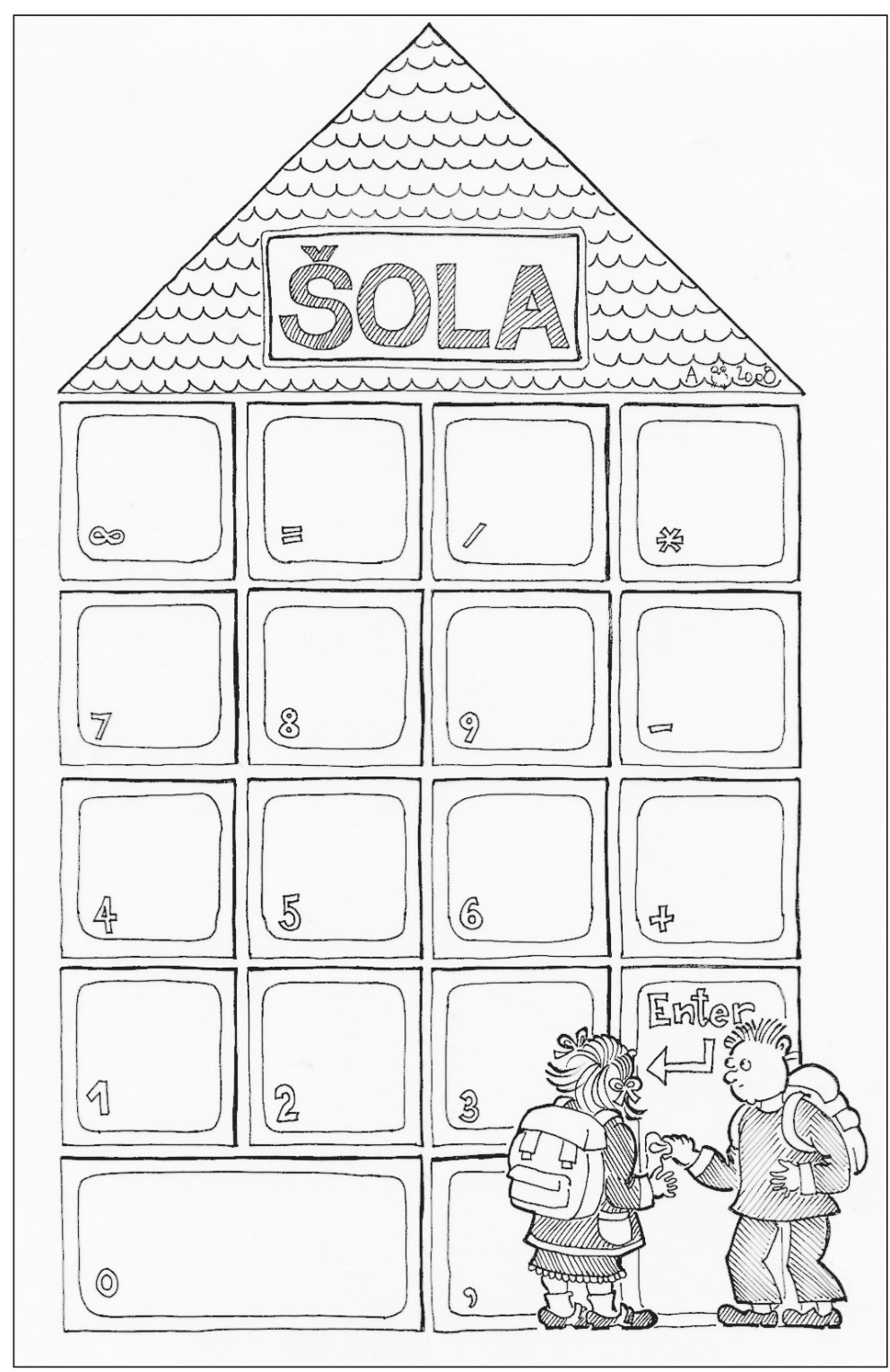

regije pa padejo v lestvico od devetih do enega odstotka. Podatki nam najlepše ponazorijo, kakšen razkorak je med možnostmi za razvoj človeškega kapitala $v$ glavnem mestu in kako zelo zaostajajo regije. Za delo in življenje v informacijski družbi potrebujejo znanje vsi prebivalci. Posledično se gospodarstvo v ljubljanski regiji laže in hitreje prilagaja novim razmeram. Pritisk ljudi na delo v Ljubljani se povečuje (Statistične informacije št. 188/ 92, 2002).

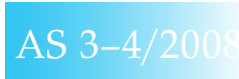


Stanje v regijah se je izboljšalo predvsem zaradi novoustanovljenih zasebnih ustanov za izobraževanje odraslih. Te so bolj fleksibilne, nastajajo na osebno pobudo in se lahko izognejo rigidnemu, birokratskemu proUporaba interneta in e-izobraževanje sta odvisna od predhodne izobrazbe ljudi.

cesu ustanavljanja novih javda se bodo razmere na podeželju spreminjale v prid boljših pogojev za učenje in razvoj. $\mathrm{K}$ temu pripomorejo tudi novonastala društva, mreža študijnih zavodov. Predvidevamo, skih krožkov po vaseh in malih krajih in spontano občasno združevanje ljudi ob posameznih dogodkih (obletnice kraja, razna praznovanja, kulturni dogodki, razstave, skupinska potovanja in podobno) (ibid.).

Raziskave RIS (Raziskovalnega inštituta Slovenije) so po letu 2000 odkrile, da se zmanjšujejo razlike med regijami in centrom pri uporabi interneta. Odprt dostop do izobraževanja prihaja z novo informacijsko-komunikacijsko tehnologijo. Dostop do znanja se demokratizira po tej poti. Od ponujenega znanja in informacij si vzame vsak v skladu s svojimi interesi in potrebami. Wikipedija je največja enciklopedija na svetu. Dostopna je vsem prebivalcem. Portali, forumi, klepetalnice, blogi, skype, elektronska pošta množijo pretok znanja spontano. Podatki o uporabnikih interneta $\mathrm{v}$ osrednji regiji in preostalih regijah se zbližujejo. Uporabnikov interneta je v osrednji regiji 40 odstotkov, v obalni, gorenjski, dolenjski in štajerski pa le nekaj odstotkov manj (od 37 do 32 odstotkov). Tudi savinjska, prekmurska in goriška regija se jim po številu približujejo, saj imajo od 28 do 24 odstotkov uporabnikov interneta (Krajnc, 2006).

\section{KDO SE LAHKO POSLUŽUJE E-IZOBRAŽEVANJA?}

Ločnica med funkcionalno pismenim delom prebivalstva in nepismenim je pri uporabi in- terneta jasno začrtana. Po podatkih empirične študije RIS interneta ne uporablja nihče $\mathrm{z}$ nedokončano osnovno šolo. Med uporabniki interneta imajo samo trije odstotki ljudi osnovno šolo in samo 13 odstotkov jih ima poklicno šolo. Število uporabnikov interneta visoko poskoči pri ljudeh s štiriletno srednjo šolo, na 43 odstotkov, višjo šolo ima 54 odstotkov uporabnikov, visoko pa 78 odstotkov. Osebe z magisterijem in doktoratom stoodstotno uporabljajo internet (ibid.). Uporaba interneta in e-izobraževanje je odvisna od predhodne izobrazbe ljudi.

Za e-izobraževanje mora biti oseba sposobna samostojnega učenja. Sama mora ločevati bistveno od nebistvenega, postavljati pravilna gesla za iskanje vsebin, poznati mora vsaj delno tuji jezik in obvladati osnove računalništva. Informacijsko-komunikacijska tehnologija ponuja neizčrpan vir informacij. Informacije po strukturiranju postanejo znanje. Za strukturiranje potrebuje učenec dovolj predhodnega znanja in široko izobrazbo. »Naučiti učiti se« je eno od štirih najbolj pomembnih področij osnovnih znanj sodobnega človeka. Poleg tega mora imeti še sposobnost odločanja, sposobnost za ustvarjanje kakovostnih medsebojnih odnosov in sposobnost komuniciranja. Evropska skupnost si prizadeva na vseh štirih področjih, kar se kaže $\mathrm{v}$ številnih projektih (Basic Skills Projects), v okviru katerih naj bi prebivalci razvili ta temeljna znanja. Od njih so odvisni preživetje, socialni mir in kakovost življenja ter dela.

Pri nas bi pospešili e-izobraževanje, če bi na državni ravni začeli odpravljati funkcionalno nepismenost kot usedlino industrijskega obdobja. V finančni in gospodarski krizi primanjkuje časa. Ukrepi morajo biti hitri. Ljudje pa potrebujejo čas, da si izobrazbo povišajo za eno ali dve stopnji.

V e-izobraževanju se učimo brez učitelja. Učenec je odvisen od svoje osebne motivacije, da se sploh odloči za učenje, da vztraja in sprejema znanje. Ni več učitelja, ki bi stal za njim. 
Sam se prebija do učnega cilja, presoja, ali zna dovolj, ali še išče naprej.

\section{LITERATURA}

Naisbitt, J. (2000): Global paradox, Avon Books, New York

Naisbit, J. (1984): Megatrends, Warner Books, New York

Toffler, A. in H. (1995): Creating a New Civilization, Turner Publishing Inc. Atlanta

Toffler, A. (1987): The Third Wave, Bantam Books, London

Toffler, A. (1991): Power Shift, Bantam Books, London

Mužić, V. (1979): Kibernetika u savremenoj pedagogiji, Školska knjiga, Zagreb

Možina, E. (2003): Funkcionalna pismenost, Andragoški center Slovenije, Ljubljana

Tough, A. (1972): Adults 'Learning Projects, OISE, Toronto

Krajnc, A. (1973): Adult Education and Social Participation, OISE, Toronto

Krajnc, A. (2006): Andragogika za učitelje (Skripta), Oddelek za pedagogiko in andragogiko, Filozofska fakulteta, Ljubljana

Statistične informacije štev. 188 /92, 2002, Zavod Republike Slovenije za statistiko, Ljubljana

E- LEARNING, Spread Digital Literacy (2008), Evropska komisija, Bruxeless

Jerman Blažič, B. (1996): Internet, Forum Ljubljana 